\title{
COMPARISON OF FISH POPULATIONS ABOVE AND BELOW A CULVERT
}

BRYAN J. TANNER and GERRY A. WILDE, Forest Technology School, P.O. Box 880, Hinton, Alberta. TOE 1 BO.

Past culvert constructions have often been installed without consideration to fish movement such as the cement culvert located on Hardisty Creek near Hinton, Alberta (Figs. 1 and 2). Therefore, a fish comparison study was conducted on Hardisty Creek in October 1978, to determine effects on pecies, numbers, total lengths and weights of fish above and below this culvert.

The creek has an average width of $3.5 \mathrm{~m}$, an average depth of $0.25 \mathrm{~m}$ and a velocity of $0.36 \mathrm{~m} / \mathrm{second}^{\prime}$ The $5 \%$ gradient for this creek is steep as compared to other creeks in the area. Three 100-m sites on the creek (Fig. 2), ne below and two above the culvert, vere chosen. All three exhibited a imilar stream gradient and close roximity to other culverts on the creek. iccessibility to the sites was another consideration in their location. Each site was electrofished using a Smith Root $V$ electrofisher ${ }^{2}$. Length, weight and number of each captured fish were recorded for each site. Previous electrofishing on creeks in the Hinton area indicated that September and October were the best months to obtain a good fish population sample.

One hundred twenty-six fish were captured at the three sites (Table 1). Below the culvert, the number of species and the total number of fish were greater than those above the culvert. Thirty-three Rainbow Trout (Salmo gairdneri) were captured above the culvert whereas, 76 Rainbow Trout, 11 Mountain Whitefish (Prosopium williamsoni), three Brook Trout (Salvelinus fontilalis), two Burbot (Lota lota) and one Pearl Dace (Semotilus margarita) were captured below the

Table 1. CATCH RECORD FOR THREE SITES ON HARDISTY CREEK.

\begin{tabular}{|c|c|c|c|c|c|}
\hline & \multicolumn{2}{|r|}{ Length $(\mathrm{cm})$} & \multicolumn{3}{|c|}{ Weight (gm) } \\
\hline Species & No. & Range & Mean & Range & Mean \\
\hline $\begin{array}{c}\text { Rainbow } \\
\text { Trout }\end{array}$ & 76 & $4.20-17.40$ & 8.71 & $0.60-61.50$ & 8.50 \\
\hline $\begin{array}{l}\text { Mountain } \\
\text { Whitefish }\end{array}$ & 11 & $9.00-14.00$ & 11.87 & $5.70-20.00$ & 12.63 \\
\hline $\begin{array}{l}\text { Brook } \\
\text { Trout }\end{array}$ & 3 & $18.60-30.00$ & 24.10 & $68.20-330.30$ & 174.17 \\
\hline Burbot & 2 & $25.00-26.00$ & 25.50 & $76.80-108.10$ & 92.45 \\
\hline $\begin{array}{l}\text { Pearl } \\
\text { Dace }\end{array}$ & 1 & 5.30 & 5.30 & 1.80 & 1.80 \\
\hline $\begin{array}{c}\text { Rainbow } \\
\text { Trout }\end{array}$ & 20 & $8.40-20.20$ & 14.08 & $6.50-80.00$ & 30.82 \\
\hline $\begin{array}{c}\text { Rainbow } \\
\text { Trout }\end{array}$ & 13 & $8.00-21.60$ & 15.67 & $5.30-118.60$ & 43.89 \\
\hline
\end{tabular}




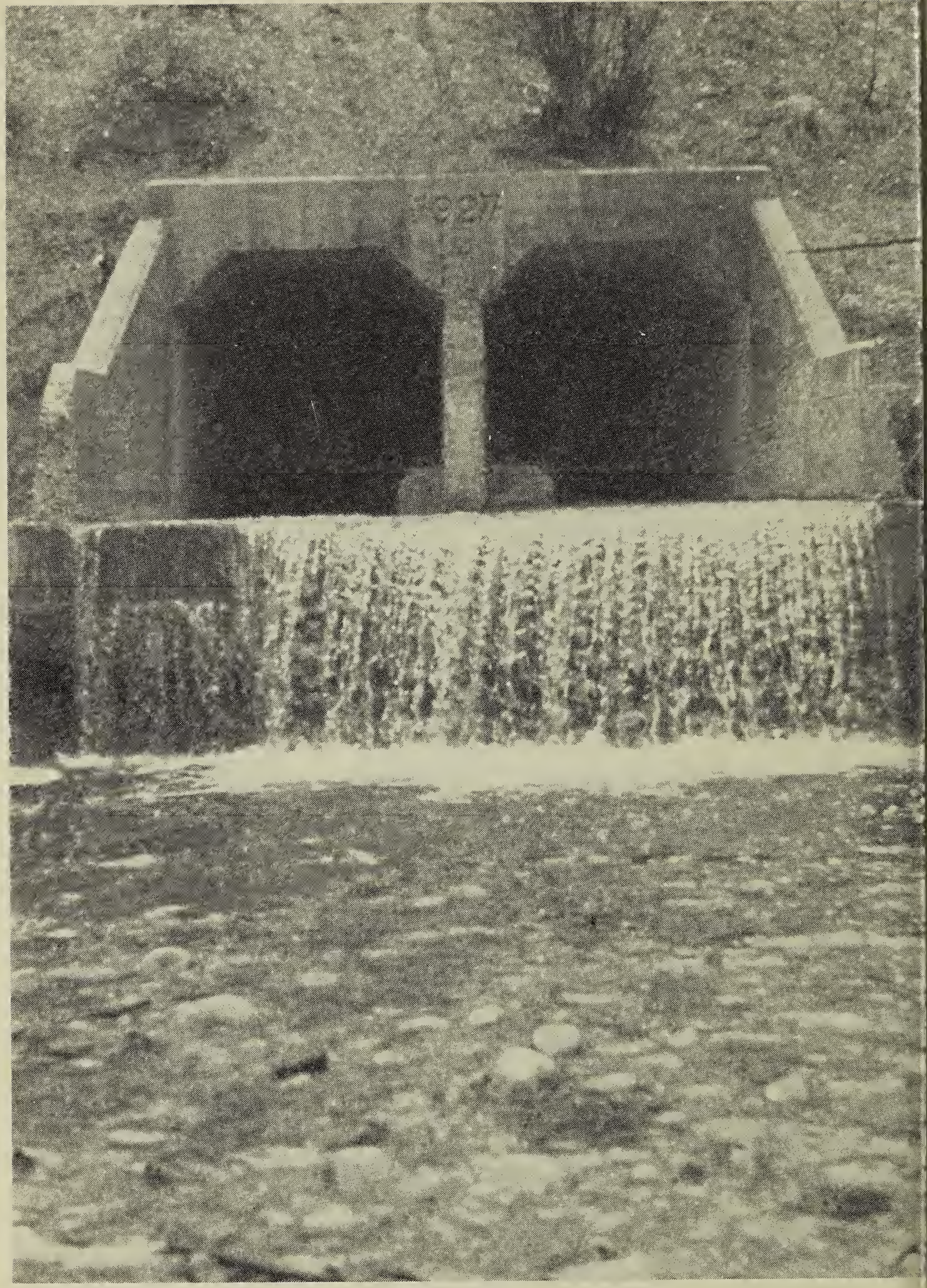

Figure 1. Cement culvert on Hardisty Creek.

G. A. Wilde

culvert. Average lengths and weights for each site indicated that Rainbow Trout above the culvert average longer and heavier than trout below the culvert (Table 1).

We believe that this culvert acts as an 


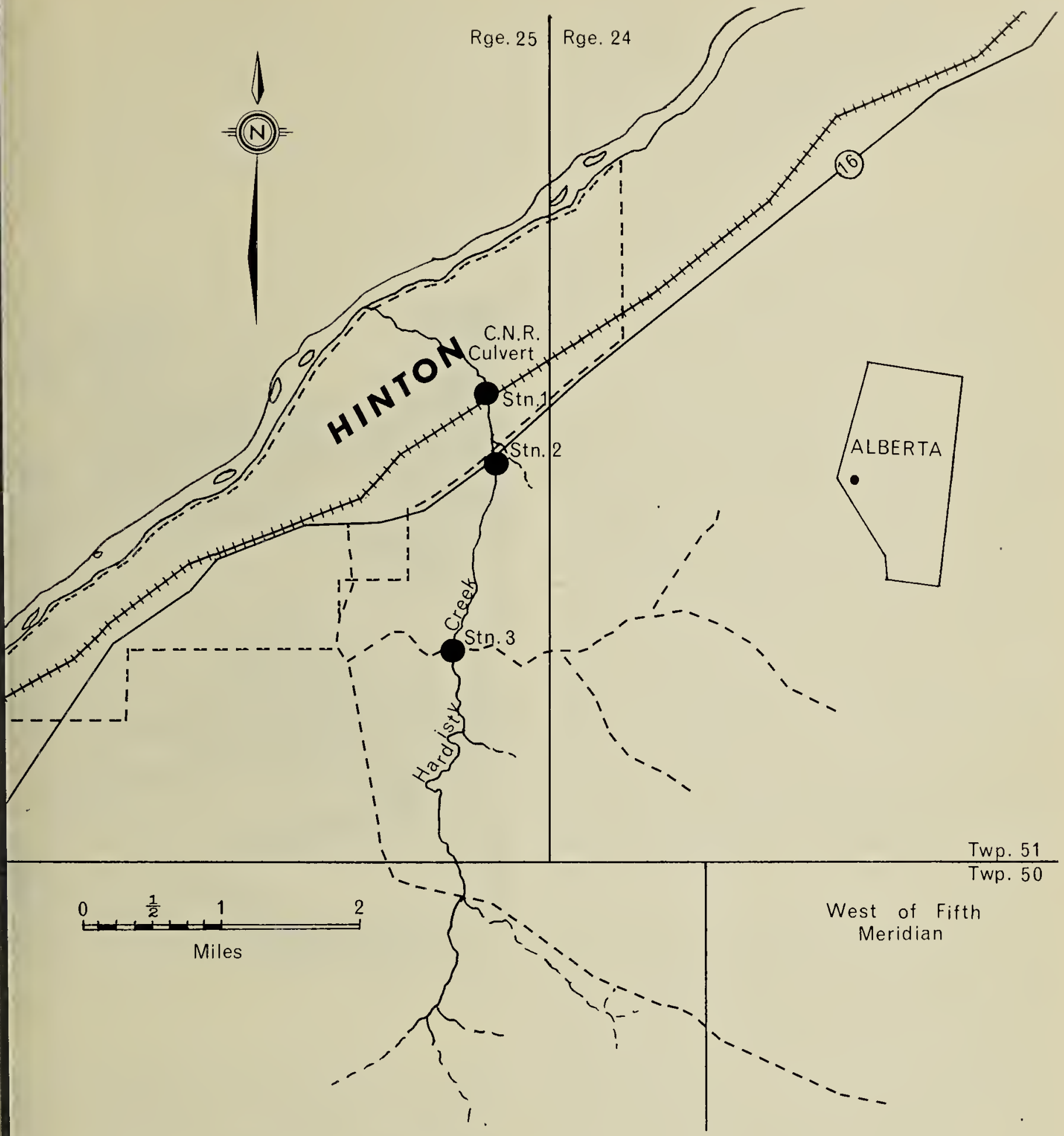

igure 2. Site Locations on Hardisty Creek.

bstacle to upstream fish movement, erefore influencing species, numbers, ngths and weights of migrating fish. le suspect that the fish above the ulvert have achieved a greater length id weight due to less competition for od among a smaller population of fish. e suggest that future creek and river ossings should provide for fish ovement and where drop-off onditions occur, fishway or gabion systems should be used ${ }^{3}$.

${ }^{1}$ DIXON, R. M. 1978. Stream survey report No. 1 - Hardisty Creek. Forest Technology School, P.O. Box 880, Hinton, Alberta.

${ }^{2}$ LAGLER, K. 1956. Freshwater fishery biology. Wm. C. Brown, Dubuque, lowa.

${ }^{3}$ WATTS, F. J. 1975. Design of culvert fishways. U.S. Dept. Agric., Missoula, Montana 